\title{
CORPORATE STRATEGY: HOW COMPANIES RESPOND TO POLITICAL STABILITY AND ECONOMIC GROWTH?
}

\author{
Asas Fitria \\ University of Airlangga, Indonesia \\ E-mail: fitriaasas@gmail.com
}

\begin{abstract}
In determining the strategy to be applied the company is very important consider the political risks and its effects on the organization. This is worth considering because changes in an action or political policy in a country can have a major impact on the country's financial and economic sectors. This study tries to study the company's strategy in responding to the political stability and economic growth of a country. The population in this study is a manufacturing company listed in Indonesia Stock Exchange in 2012-2016. These results indicate that political stability and economy growth directly influence the corporate strategy.
\end{abstract}

\section{KEY WORDS}

Political stability, economy growth, corporate strategy, public service.

In a democratic country like in Indonesia it cannot be separated from the political world. The political world becomes the subject of conversation in every institution, because the existence of the political world can attract every circle. It cannot be denied that one of the successes of a company cannot be separated from the influence of the political environment of a country. The objectives of politics to formulate public policy include the interests of the business world. Conversely, the business world can support the politics of a country, it can be said that business and politics are two things that are related.

Politics is the behavior, actions of government, parliament, parties, and organizations to achieve a goal, especially in relation to the fields of state life and to organize community life together. Within this framework, politics is understood as a practical, calculated attitude and step of life to achieve a goal maximally and effectively (Cengga 2017).

Economic growth is one of the most important indicators to assess the economic performance of a country. Economic growth usually measured by indicators of Gross Domestic Product (GDP) shows the extent to which the performance of the economic sectors in generating output (Septiani, 2014). In 1998 Indonesia experienced a prolonged crisis that resulted in many companies that eventually went bankrupt, allegedly due to weak corporate governance at the time. Therefore, corporate governance gets serious attention both for government and investors (Lestari, 2017).

Chandrawibowo (2009) explains that the direction and stability of political factors is an important consideration for managers in formulating corporate strategy. Political factors determine the legal and regulatory parameters that limit the company's operations. Political constraints imposed on firms through decisions on fair trade, antitute law, taxation programs, minimum wage provisions, pollution and pricing policies, administrative boundaries, and more measures intended to protect workers, consumers, the public, and environment. Because such laws and regulations are usually restrictive, they tend to reduce the company's profit potential. However, some political measures are designed to protect and benefit the company. Such actions include patent laws, government subsidies, and product research fund grants. Thus, political factors can limit or benefit the affected company.

In determining the strategy to be applied the company is very important consider the political risks and its effects on the organization. This is worth considering because changes in an action or political policy in a country can have a major impact on the country's financial and economic sectors. Political risk is generally closely related to government and the political and security situation in a country.

This study tries to study the company's strategy in responding to the political stability 
and economic growth of a country. Management requires a strategy as a tool to win the competition and maintain the survival of the company. Strategy is a pattern of decisions and specific actions that enable managers to achieve organizational goals (Hill and Jones, 1998). Hill and Jones (1998) also define strategic change as the movement of what is being done right now into the future in order to increase the competitive advantage.

This study refers to previous researches conducted by Isa (1996), Feng (1997), Musyarofah (2003), Armah (2009), Li, Weiwen (2012), Ngan (2013), Donnelly (2013), Cheng \& Leung (2015), Li, Sihai (2015), Harymawan (2016), Chen (2017) outline the studies discuss how the company's role of political connections and the impact of political connections in various countries. As the research conducted by Harymawan (2016) "find that the earnings quality of politically connected firms increases as government effectiveness improves, but decreases as the political environment becomes more stable". Feng (1997) found "democracy has an indirect effect on growth through its impact on the probability of regime change and the change of constitutional government from one ruling party to another".

Therefore, in this study intends to review the problem of political stability in developing countries such as Indonesia in the face of democratic period of general election of State officials. The focus of this research is to see how the country's political stability influences the company's strategic change with intervening variable of economic growth. The purpose of this study is to see the existence of political stability with the relationship with the company's management of the company's strategy. So it can be explained that the political situation of a State becomes one of the factors changing the company's strategy so it is expected to support the phenomenon that politically related executives can function as disciplinary or monitoring mechanisms in political economy. The population in this study is a manufacturing company listed in Indonesia Stock Exchange in 2012-2016. The results of this study provide evidence that the Political stability influence to Economy Growth, Economy Growth influence on Corporate Strategy and Political Stability can directly affect Corporate Strategy.

\section{LITERATURE REVIEW}

Legitimacy of society is a strategic factor for the company in order to develop the company in the future; it can be used as a vehicle to construct company strategy, especially related to positioning itself in the middle of an increasingly advanced society (Hadi, 2011: 87). Deegan (2002) expresses legitimacy as "... a system oriented perspective, the entity is assumed to be influenced by, and in turn, the society in which it operates. Corporate disclosure is considered to represent one important means by which management can influence external perceptions about organization".

Sudaryanto (2011: 14) states that the company has a contract with the community to conduct its activities based on the values prevailing in the community, and how the company responds to various corporate interest groups.

Political theory is the discussion and generalization of political phenomenon. In other words, political theory is discussed above, a) the purpose of political activity, b) the ways to achieve it, c) the possibilities and needs arising from certain political situations and d) the obligations resulting from the political objectives. The concepts discussed in political theory include, among others, society, social class, state, power, sovereignty, rights and duties, independence, state institutions, social change, political development, modernization and so forth. (Budiharjo, 1992: 30).

Stability is a condition of a system whose components tend to be in or back to a stable relationship (Jack et al., 1989; Syahrul Romadhon, 2006). Political Stability can be understood as a condition in which there is no fundamental change or what is revolutionary in the political system (government), or changes occurring at defined limits (Plano, 1985, Syahrul Romadhon, 2006)

In some theoretical studies looking at the relationship of corporate political connections can benefit from being better able to understand the process of public policy, gain direct access to politicians, and provide legitimacy by relating the reputation and status of the 
company (Hillman, 2005; Harymawan, 2016). In the research (Harymawan, 2016) shows a change in the Political Stability of government actions on market performance and improving the quality of accounting information.

Kuznets (Jhingan, 2000) defines economic growth as a long-term increase in a country's ability to provide more types of economic goods to its population. This capability grows according to technological progress, and the institutional and ideological adjustments required by the residents of the country in question. This definition has three main components; (1) the economic growth of a nation is seen and the continuous increase of supply of goods, (2) advanced technology is a factor in economic growth that determines the degree of capability growth in the provision of various goods to the population, and (3) the widespread and efficient use of technology requires an adjustment in the institutional and ideological fields so that the innovations produced by human science can be properly utilized. Sadono Sukirno (2000) defines economic growth as a change in the level of economic activity prevailing from year to year. An economy is said to be growing if the level of economic activity is higher than what has been achieved in the previous time period. The rate of economic growth is measured by the rate of GDP at constant prices.

Boediono (1992) defines economic growth as a process of increasing per capita output over a long period of time. Economic growth includes three aspects; (1) economic growth is an economic process, namely; change from time to time, (2) economic growth is closely related to two important aspects of total output and population, and (3) economic growth is said to increase if per-capita output increases over the long term.

Strategy in KBBI (1990: 859) is a war strategy or science of war strategy. Strategies can also be said to be a careful plan for activities to achieve specific targets. Potter (1998) says strategy as an art and science of formulating, implementing, and evaluating strategic decisions between functions that enable an organization to achieve its goals in the future.

Porter (1985) describes three different generic strategies at the business level: cost leadership, differentiation and focus. Meanwhile, Miles and Snow see the type of strategy not based on the level of strategy but on the level of changes in market and product orientation. There are four types of business strategies identified by Miles and Snow (1978) according to the level of product or market change: prospectors, defenders, analyzers and reactors. Hill and Jones (1998) define strategic change as the movement of what is being done right now into the future in order to increase competitive advantage. Strategic changes made can be: (1) reengineering (2) restructuring and (3) innovation.

\section{HYPOTHESES DEVELOPMENT}

Political Stability on Economic Growth. In determining the strategy to be applied the company is very important consider the political risks and its effects on the organization. This is worth considering because changes in an action or political policy in a country can have a major impact on the country's financial and economic sectors. Political risk is generally closely related to government and the political and security situation in a country. It can not be denied that one of the success of a company can not be separated from the influence of the political environment. The objectives of politics to formulate public policy include the interests of the business world. Conversely, the business world can support the politics of a country, it can be said that business and politics are two things that are related. Several studies of political stability and economic growth were carried out by Isa (1996), Feng (1997), Romadhon (2006), Aisen and Jose (2010), Septian (2014) Sen et al (2014), Facchini and Melki (2013), Uddin et al (2017), Ali and Azmi (2017), Cox and Weingast (2018). Therefore the first hypothesis in this study:

H1: Political Stability has a positive effect on Economic Growth.

Economic Growth to Corporate Strategy. Ali (2009) revealed the quality of an institution will determine economic growth. Weak institutions will disrupt economic growth because it causes economic agents to struggle against a bad institutional system rather than continue economic activity. One form of institution within a country is politics. Politics has an influence in the economy because politics will provide a restriction and market environment as a form 
of control over consumers and companies (Drazen, 2001). Several studies related to economic growth with company strategy Peng et al (2008), Augier and Teece (2009), Urata et al (2009), therefore the second hypothesis in this study:

$\mathrm{H} 2$ : Economic Growth positively affects Corporate Strategy.

Political Stability on Corporate Strategy. Every action in an organization is political, except charity or social organization. These factors determine the smooth running of a business. Therefore, if the political situation supports, then business will generally run smoothly. In terms of the stock market, a conducive political situation will make stock prices rise. Conversely, if the political situation is uncertain, it will create an element of uncertainty in the business. Some research on political stability and corporate strategy is carried out by Armah (2009), Antia et al (2012), Badelea and Fundeanua (2014), Waisman et al (2015), Unsal et al (2016), Cheng (2016), Gama et al (2018). Therefore the third hypothesis in this study:

H3: Political Stability directly affects Corporate Strategy.

\section{METHODS OF RESEARCH}

The population in this study is a manufacturing company listed in Indonesia Stock Exchange in 2012-2016. However, because this study looks at changes in corporate strategy involved in Political Stability, this study uses a proportional method in determining the sample.

For Political Stability (PS) variables, we rely on indexes provided by WGI World Bank. Stability is a condition of a system whose components tend to be in or back to a stable relationship (Jack et al., 1989; Munaqosyah, 2006). Political Stability Measurement using index ranges from -2.5 to 2.5 higher values represents a more stable political situation.

For variable Corporate Strategy (CS) researcher use method in research of Balsam et al (2011); Chang et al (2015); Wibowo et.al (2017) used to measure product strategy with Sales / CoGS Ratio is the ratio of net sales to cost of goods sold or cost of sales. Companies that implement cost leadership strategies try to minimize cost of goods sold compared to companies that implement product differentiation strategy.

The intervening variable is the interrupt variable located between the dependent variable and the independent variable (Sugiyono, 2007). The purpose of this intervening variable is to examine the direct and indirect effects of independent variables on the dependent variable, then it will be drawn a conclusion whether this intervening variable can strengthen or even weaken the independent influence on the dependent.

Measurement of Economic Growth (EG) in a country / region is usually calculated by a percentage of Gross Domestic Product (GDP). Gross Domestic Product (GDP) is total revenue and total national expenditure on output of goods and services. The purpose of GDP is to summarize economic activity in a particular money value over a period of time (Mankiw, 2007).

The control variable as the independent variable controller can explain the existence of the dependent variable. Use of control variables is to avoid any element of bias research results. So the result of research by using control variable will minimize bias compared with research without using control variable. The control variables used in this research are:

The size of a company is determined by its asset size. The greater the total assets owned by a company, the company is considered to have good prospects in the long term. In addition, companies with a large asset are considered relatively stable and more able to generate profits. The indicator variable to represent the firm's size factor is the total assets owned by the company (Hay et al., 2008). The firm size in this variable will be measured using the natural logarithm of the company's total assets at the end of the year. This variable is then denoted by SIZE.

ROA is a ratio that measures the ability of firms to generate profits by using the total assets (wealth) owned by the company after adjusted for the costs to fund the asset. This variable is denoted by ROA: Net profit after tax is the company's operating profit derived from the company's principal transactions net of tax; Total assets represent total assets owned by 
the company, either current assets, fixed assets, or intangible assets.

Age of the company in this study is the length of life of a company that shows that the company still exist and able to compete in the business world and able to maintain the continuity of its business (Seragih, 2015).

According Syamsudin (2001: 89), the term leverage is usually used to describe the ability of companies to use assets or funds that have fixed costs (fixed cost assets or funds) to increase the level of income (return) for the owner of the company. According to Samani (2008), the proportion of leverage (LEV) is measured by the ratio of total debt to total assets. The proportion of leverage is expressed in percentage.

Company growth is measured by price book value (PBV), which is divided by book value per share.

The method of analysis used in this study is the regression model. The regression model derived from the Ordinary Least Square (OLS) method is a regression model that produces the best linear estimate (BLUE) estimator. Test $F$ (simultaneous) is done by comparing the level of significance $F$ of test results with significance value used in this study. Next Test $t$ (Partial) Testing is done by using significance level $0.05(\alpha=5 \%)$.

In this study also uses path analysis (path analysis), which is an extension of multiple linear regression analysis. Path analysis is used to test the influence of intervening variables in this study. The results of this path analysis test will also be used to compare which effect is greater between direct and indirect effects, as well as to draw a conclusion as to whether this intervening variable can strengthen or weaken the independent influence on dependents (Ghozali, 2009).

\section{RESULTS OF STUDY}

In table 1 , the average Economic Growth in $2012-2016$ is $4.53 \%$, while Political Stability still holds negative value, i.e. -0.43 which means Indonesian political power in 20212-2016 is still relatively weak as WIG indexes are raised, Corporate Strategy manufacturing in cost ratio has an average of 1,153 .

Table 1 - Descriptive Statistics

\begin{tabular}{lllll}
\hline & Minimum & Maximum & Mean & Std. Deviation \\
\hline Economic Growth & 4,18 & 5,28 & 4,5302 &, 42288 \\
Political Stability &,- 55 &,- 29 &,- 4311 &, 10516 \\
Corporate Strategic & $-2,14$ & 22,06 & 1,1537 &, 96133 \\
Company Size & 11,40 & 19,75 & 14,6403 & 1,81466 \\
Return on Asset & $-20,80$ & 74,84 & 5,4397 & 9,10781 \\
Age & 15,00 & 111,00 & 36,1491 & 18,50057 \\
Leverage &, 12 & 2,88 &, 5559 &, 42088 \\
Company Growth &,- 69 & 9,33 & 1,5072 & 1,61915 \\
Valid N (listwise) & & & & \\
\hline
\end{tabular}

Table 2 - Test the control variables

\begin{tabular}{llll}
\hline Variable & Predicted significance & $\mathrm{t}$ & Sig. \\
\hline Company Size & + & 1,016 &, 310 \\
Return on Asset & + & 6,843 &, 000 \\
Age & + &, 143 &, 887 \\
Leverage & - &,- 430 &, 668 \\
Company Growth & + & 4,553 &, 000 \\
a. Dependent Variable: Corporate Strategy & & \\
\hline
\end{tabular}

Based on the value of $5 \%$ trust in the table seen ROA variable and Growth of the company (growth) effect on Corporate Strategy. In testing the first hypothesis then here seen the value of R-square from Political Stability variable on Economic Growth has value 0,207 or $20,7 \%$ which means $20,7 \%$ Political Stability variable can explain in Economic Growth variable but the remaining $79,3 \%$ is influenced by other variable. Because many other variables that can affect the economic growth of a country. 
Table 3 - Summary Model (Political Stability- Economic Growth)

\begin{tabular}{lllll}
\hline Model & $\mathrm{R}$ & $\mathrm{R}$ Square & Adjusted R Square & Std. Error of the Estimate \\
\hline 1 &, $455 \mathrm{a}$ &, 207 &, 206 &, 37685 \\
\hline
\end{tabular}

Table 4 - Political Stability- Economic Growth

\begin{tabular}{|c|c|c|c|c|c|c|}
\hline \multicolumn{7}{|c|}{ Coefficients } \\
\hline & & $\begin{array}{l}\text { Unstar } \\
\text { B }\end{array}$ & $\begin{array}{l}\text { d Coefficients } \\
\text { Std. Error }\end{array}$ & $\begin{array}{l}\text { Standardized Coefficients } \\
\text { Beta }\end{array}$ & $\mathrm{t}$ & Sig. \\
\hline 1 & $\begin{array}{l}\text { (Constant) } \\
\text { PS }\end{array}$ & $\begin{array}{l}3,741 \\
-1,831\end{array}$ & $\begin{array}{l}067 \\
150\end{array}$ &,- 455 & $\begin{array}{l}56,080 \\
-12,175\end{array}$ & $\begin{array}{l}.000 \\
.000\end{array}$ \\
\hline
\end{tabular}

From the results of hypothesis testing using t test value that the value of significance of 0.000 is smaller than 0.05 with $5 \%$ confidence value, it can be said Ho rejected or $\mathrm{H} 1$ accepted that Political Stability positively positive to the Economic Growth.

Table 5 - Summary Model (Economic Growth - Corporate Strategy)

\begin{tabular}{lllll}
\hline Model & $\mathrm{R}$ & $\mathrm{R}$ Square & Adjusted R Square & Std. Error of the Estimate \\
\hline 1 &, $763 \mathrm{a}$ &, 582 &, 582 &, 97086 \\
\hline
\end{tabular}

In testing the second hypothesis then here seen the value of $\mathrm{R}$ squere from Economic Growth variable on Corporate Strategy has a value of 0.582 or $58.2 \%$ which means $58.2 \%$ Economic Growth variables can explain in the variable Corporate Strategy but the remaining $41.8 \%$ is influenced by other variables. Because in determining the strategy to be taken by the company, the company or management will consider the external factors one of which is the country's economic growth in this case is to see the GDP of Indonesia.

Table 6 - Economic Growth - Corporate Strategy

\begin{tabular}{|c|c|c|c|c|}
\hline \\
\hline \multirow{2}{*}{$\begin{array}{l}\text { Coefficients } \\
\text { Model }\end{array}$} & \multirow{2}{*}{$\begin{array}{l}\text { Unstandardized Coefficients } \\
\text { B }\end{array}$} & & \multirow[t]{2}{*}{$\mathrm{t}$} & \\
\hline & & \multirow{2}{*}{\begin{tabular}{ll}
\multicolumn{2}{c}{ Standardized Coefficients } \\
Std. Error & Beta \\
, 009 &, 763 \\
\end{tabular}} & & \\
\hline $\begin{array}{l}\text { Ooefficients } \\
\text { Model } \\
\text { FG }\end{array}$ & $\begin{array}{lll}E G & , 252\end{array}$ & & $28,149,000$ & \\
\hline
\end{tabular}

From the results of the second hypothesis testing using $t$ test value that the significance value of 0.000 is smaller than 0.05 with a confidence value of $5 \%$, it can be said Ho rejected or $\mathrm{H} 1$ accepted, i.e. Economic Growth positive effect positive to Corporate Strategy.

Table 7 - Summary Model (Political Stability - Corporate Strategy)

\begin{tabular}{lllll}
\hline Model & $\mathrm{R}$ & $\mathrm{R}$ Squareb & Adjusted R Square & Std. Error of the Estimate \\
\hline 1 &, $765 a$ &, 585 &, 583 &, 96882 \\
\hline
\end{tabular}

In testing the third hypothesis, it can be seen that the $\mathrm{R}$ squere value of Political Stability and Economic Growth variables on Corporate Strategy has a value of 0.585 or $58.5 \%$ which means that $58.5 \%$ of Political Stability and Economic Growth variables can be explained in Corporate Strategy variable but the remaining $41,5 \%$ influenced by other variables. Because in determining the strategy to be taken by the company, the company or management will consider external factors one of them is the economic growth of the country which in this case is to see the GDP of Indonesia, as well as the Political Stability of the country.

Table 8 - Political Stability- Economic Growth - Corporate Strategy

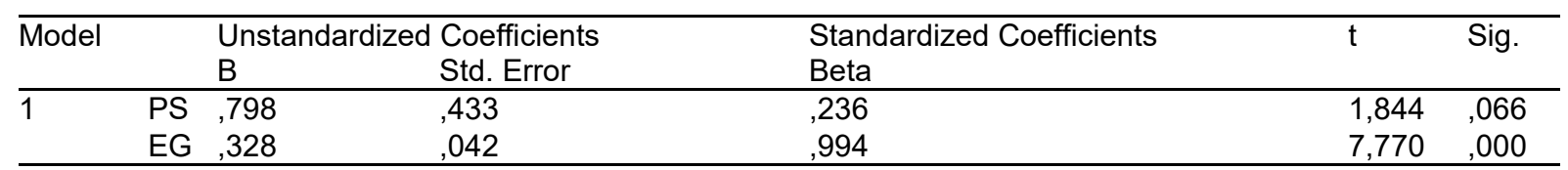


The direct effect of PS given to CS is 0.236 , whereas the indirect effect of PS to EG is the multiplication of beta value of PS to EG with beta value of EG to CS, i.e -0.347 . Then the total effect given by PS to CS is direct influence plus indirect effect that is $-0,111$. Based on the results of the calculation is known that the value of direct influence of 0.236 and indirect influence of -0.111 which means that the value of direct influence is greater than the value of indirect influence, these results indicate that directly PS has an influence on CS. Then $\mathrm{H} 1$ is acceptable.

\section{CONCLUSION}

From the tests conducted by the researchers found First, Political Stability has an influence on Economic Growth it supports several studies such as yang dilalukan by Yi feng (1997); Uddin et.al (2017) proves the relationship between politics and economics, so that economic development is dependent or determined by the existing political environment. Secondly, Economic Growth has an influence on Corporate Strategy that supports Augier and Teece (2002); Mike et.al (2008) indicates that in determining the company's strategy the economic factor is an external factor that must be considered by management. Thirdly, Political Stability directly affects Corporate Strategy in line with the research by Kathleen et.al (1988) as well as economic factors; political factors are also taken into consideration in determining the company's strategy.

Companies that want to be successful should be able to develop a plan map to achieve the mission we call a strategy, where Strategy is a plan to achieve success in the competition (Hezron, et al, 2012). Management requires a strategy as a tool to win the competition and maintain the survival of the company. Strategy is a pattern of decisions and specific actions that enable managers to achieve organizational goals (Hill and Jones, 1998).

In an effort to achieve success the role of management is very important. This is closely related to the task and function of using cost management information that includes financial information on costs and revenues as well as nonfinancial information and other key determinants of success for the organization. In determining the strategy that will be applied the company that is considering political and economic risks. This is worth considering because changes in an action or political policy in a country can have a major impact on the country's financial and economic sectors. It cannot be denied that one of the successes of a company cannot be separated from the influence of the political environment. The objectives of politics to formulate public policy include the interests of the business world. Conversely, the business world can support the politics of a country, it can be said that business and politics are two things that are related.

Limitations of this study are measurements used by researchers in measuring corporate strategy and identification of factors, other due to some obstacles in data search. Subsequent research should be broader in the measurement of corporate strategy, and can add several factors that may affect the company's strategy.

\section{REFERENCES}

1. Ali, Mohammad. 2009. Pendidikan untuk Pembangunan Nasional. Bandung: Imperial Bakti Utama

2. Armah, Stephen.E. 2009. Investigating the Influence of Political Stability of the AidGrowth Relationship in Sub Saharan Africa: A Panel Data Approach. Journal of Economic Development, Management, IT, Finance and Marketing.

3. Balsam, S., Fernando, G. D., \& Tripathy, A. (2011). The Impact of Firm Strategy on Performance Measures Used in Executive Compensation. Journal of Business Research, 187-193.

4. Boediono. 1992. Teori Pertumbuhan Ekonomi. Yogyakarta, BPFE UGM. Budihardjo, E., 1992, Sejumlah Masalah Permukiman Kota, Alumni, Bandung.

5. Cengga, H. Etimologi dan Fenomena Politik di Indonesia Sampai Saat ini. Publish Kompasiana (online). (https://www.kompasiana.com/cambirbendera/) 
6. Chandrawibowo. 2009.2 Manajemen Diakses: https://chandrawibowo0789.wordpress.com/2009/10/11/manajemen-strategik4/

7. Chang, H., Fernando, G. D., \& Tripathy, A. (2015). An Empirical Study of Strategic Positioning and Production Efficiency. Hindawi Publishing Corporation.

8. Chen, Donghua, et al. 2017. Political connection of financial intermediaries: Evidence from China's IPO mark. Journal of Banking and Finance 76 (2017) 15-31.

9. Cheng, Lois T.W., leung, T.Y. 2016. Goverment protection, polotical connection and management turnover in China. International Review of Economics and Finance 45 (2016) 160-176.

10. Donnelly, Shawn. 2013. Power Politics and the Undersupply of Financial Stability in Europe. Forthcoming in Review of International Political Economy 2013/14.

11. Drazen, Alan. 2001. "The Political Business Cycle After 25 Years", NBER Macroeconomics Annual 2000, Volume 15, 2001.

12. Faccio, M. 2006. Pollitically conennted firms. Am. Econ. Rev. 96, 369-386.

13. Feng, Yi. 1997. Democracy, Political Stability and Economic Growth. British Journal of Political Science.

14. Ghozali, Imam. (2009). Aplikasi Analisis Multivariate Dengan Program Spss. Edisi Iv. Semarang: Badan Penerbit Universitas Diponegoro

15. Harymawan, Iman \& John Nowland, (2016),"Political connections and earnings quality How do connected firms respond to changes in political stability and government effectiveness?", International Journal of Accounting \& Information Management, Vol. 24 Iss 4 pp. 339-356.

16. Hill, Jones, (1988), Strategic Management Theory. Fourth Editions. Houghton Mifflin Company.

17. Hil man, A. (2005), "Politicians on the board of directors: do connections affect the bottom line?" Journal of Management, Vol. 31, pp. 464-481.

18. Isa, M., Rustom. 1996. Political Stability and Economic Growth in Malaysia. Pakistan Institute of International Affairs.

19. Kamus Besar Bahasa Indonesia. (1990). Jakarta: balai Pustaka.

20. Lestari, Gusti Ayu Widya dan I.G.A.M Asri Dwija Putri. 2017. Pengaruh Corporate Governance, Koneksi Politik, Dan Leverage Terhadap Penghindaran Pajak. ISSN: 23028556 E-Jurnal Akuntansi Universitas Udayana Vol.18.3.

21. Li, Sihai., Song, Xianzhong., Wu, Huiying. 2015. Political Connection, Ownership Structure, and Corporate Philanthropy in China: A Strategic-Political Perspective. J Bus Ethics (2015) 129:399-411 DOI 10.1007/s10551-014-2167-y.

22. Li, Weiwen, et al. 2012. Political connections and corporate diversification in emerging economies: Evidence from China. Asia Pac J Manag (2012) 29:799-818 DOI 10.1007/s10490-011-9265-5.

23. Jhingan, M.L. 2000. Ekonomi Pembangunan dan Perencanaan. Jakarta: Rajawali. Lembaga Ketahanan Nasional. 1995. Pembangunan Nasional. Balai Pustaka. Jakarta.

24. Mankiw, N. Gregory, 2007. Makroekonomi. Edisi Keenam. Jakarta: Erlangga.

25. Miles, R.E. dan C.C. Snow, 1978, Organizational Strategy, Structure, and Process, New York: Mc Graw-Hill.

26. Musyarofah, Siti. 2003. Pengaruh Penggunaan Anggaran Dan Gaya Manajemen Terhadap Hubungan Antara Perubahan Strategik Dan Kinerja Organisasi. Simposium Nasional Akuntansi Vi Surabaya, 2003.

27. Ngan, Sai Chung. 2013. The impact of politically-connected executives in fraudulent financial reporting: Evidence based on the $\mathrm{H}$ shares. Vol. 7(18), pp. 1875-1884, 14 May, 2013 DOI: 10.5897/AJBM12.530.

28. Plano, J.A. 1985. Kamus Analisa Politik, terj: Edi S. Suregar. Jakarta: Rajawali Press. Plano, J.C. et al. 1989. Kamus Analisa Politik. Jakarta: Rajawali.

29. Porter, M.E. 1985. Competitive Advantage: Creating and Sustaining Superior Performance: with a new introduction. The Free Press. New York, USA.

30. Porter, Michael E. 1998. Competitive Strategy: Techniques for Analyzing Industries and Competitors. New York: The Free Press. 
31. Rovelino Dan Sotartagam, Q. 2015. Analisis Pengaruh Political Connection Terhadap Nilai Perusahaan Skripsi Fakultas Ekonomika Dan Bisnis Universitas Diponegoro Semarang.

32. Sukirno, Sadono. 2000. Makroekonomi Modern. Jakarta: PT Raja Drafindo Persada. Sugiyono. 2007. Metode Penelitian Kuantitatif Kualitatif dan R\&D. Bandung: Alfabeta.

33. Romadhon S. 2006. Hubungan Stabilitas Politik dan Tingkat Pertumbuhan Ekonomi di Indonesia pada Masa Reformasi.

34. Septiani, D.P. 2014. Pertumbuhan Ekonomi Dan Kestabilan Politik Di Indonesia Fakultas Ekonomika Dan Bisnis Universitas Diponegoro.

35. Tannenbaum, R dan Schmid. 1973. How to Choose A Leadership Pattern Harvard Bussiness Review.

36. Wibowo, Handayani dan Lestari. 2017. Strategi Bersaing Perusahaan Dan Kinerja Perusahaan. Riset Akuntansi dan Keuangan Indonesia, 2(2). 